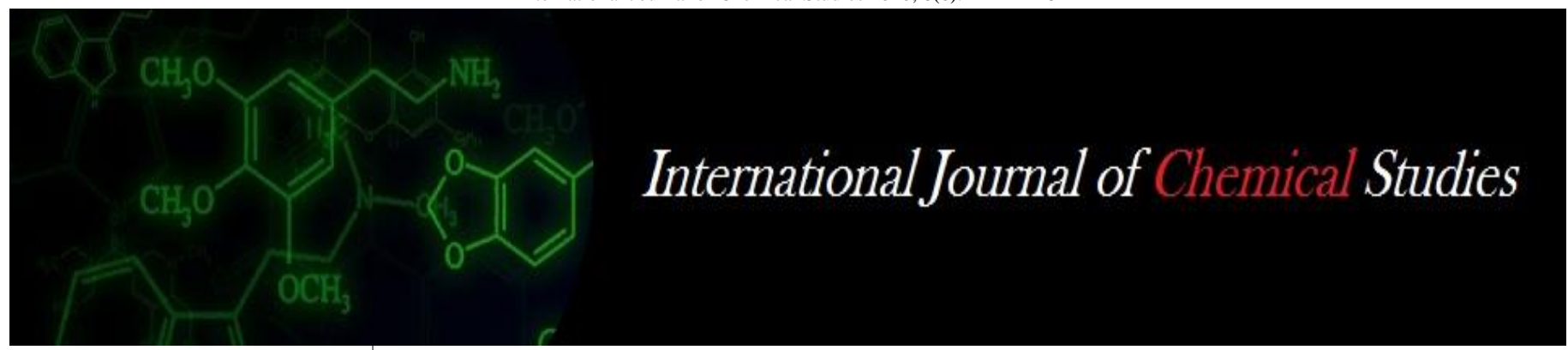

P-ISSN: 2349-8528

E-ISSN: 2321-4902

www.chemijournal.com

IJCS 2020; 8(6): 2412-2415

(C) 2020 IJCS

Received: 02-09-2020

Accepted: 10-10-2020

Har Mohan Singh Yadav

Lovely Professional University,

Phagwara, Jalandhar, Punjab,

India

Mohd. Javed

Shri Megh Singh Mahavidyalaya Abidgarh, Agra, Uttar Pradesh,

India

Devendra Pal

Krishi Vigyan Kendra Sambhal

SVPUA \& T Meerut, Uttar

Pradesh, India

Vipin Kumar

R.B.S. College Bichpuri, Agra,

Uttar Pradesh, India

Nidhi Nagar

R.B.S. College Bichpuri, Agra,

Uttar Pradesh, India

Vinay Singh

R.B.S. College Bichpuri, Agra,

Uttar Pradesh, India
Corresponding Author:

Har Mohan Singh Yadav

Lovely Professional University,

Phagwara, Jalandhar, Punjab,

India

\section{To study the interaction effect of FexMn on yield, chemical composition and nutrient uptake at various cuttings of spinach plants and grain, straw at maturity}

\author{
Har Mohan Singh Yadav, Mohd. Javed, Devendra Pal, Vipin Kumar, \\ Nidhi Nagar and Vinay Singh
}

DOI: https://doi.org/10.22271/chemi.2020.v8.i6ai.11131

\begin{abstract}
A pot experiment was conducted at pot culture yard in Department of Agricultural Chemistry and Soil Science, R.B.S. College Bichpuri, Agra (UP). To study the interaction effect of ( $\mathrm{Fe} \times \mathrm{Mn})$ on yields, chemical composition of plants at different growth stages and uptake of nutrients by grain and the straw at maturity by spinach crop. Four levels $(0,5,10,20 \mathrm{ppm})$ of each iron and manganese were evaluated in factorial design with three replications. The results indicated that the interaction of effect of $(\mathrm{Fe} \times \mathrm{Mn})$ on yields was found to be significant. The maximum values $(19.5,49.0 \mathrm{mg} / \mathrm{pot})$ of green foliage and dry matter $(2.4,5.6 \mathrm{mg} / \mathrm{pot})$ were noted under $10 \mathrm{ppm} \mathrm{Fe}+10 \mathrm{ppm}$ manganese dose. The highest dose (20 ppm iron and $20 \mathrm{ppm}$ manganese) reduce the yields upto minimum levels. Nutrient composition of spinach plants grain and straw in respect of $\mathrm{N}, \mathrm{P}, \mathrm{Fe}, \mathrm{Mn}$ content was consistently increase up to (10 ppm) dose of iron and manganese level. Thereafter, a deduction was noted with higher dose (20 ppm) iron and manganese. Similar tend was noted in case of nutrients uptake by spinach plants. It is concluded from the results that $(\mathrm{Fe} \times \mathrm{Mn})$ with dose of $10 \mathrm{ppm}$ was found to significantly superior over rest of the combinations. Investigations also revealed that $\mathrm{Fe}$ and $\mathrm{Mn}$ has antagonistic relation in respect their content and uptake in all the growth stages of spinach plants.
\end{abstract}

Keywords: Interaction, FexMn, chemical composition, spinach, maturity

\section{Introduction}

In order to boost up crop production per unit area per unit time, increasing emphasis is being laid on cultivation of high yielding varieties of crops intensive cropping heavy fertilization and modern techniques of cultivation. In this context, importance of micronutrients can hardly be over emphasized as in many areas their supply in soil may become a limiting factor in obtaining maximum levels of crop yields. In several parts of the country micronutrients disorders have been recognised as major cause of crop failure and poor productivity (Takkar and Randhawa, 1978) ${ }^{[11]}$. Substantial improvement in the performance of crop have been reported as a result of micronutrient supplement of soil for crop from different parts of country (Kanwar and Randhawa, 1974, Katyal, 1986) ${ }^{[5,6]}$. Thus the need for knowledge of micronutrients status of soil assumes still greater importance in view of increased hectare yields. Among various micronutrients, manganese is especially important owing to its typical and complex behaviour in soils besides, its vital and indispensable role in plant growth. Manganese functions in the activation of numerous enzymes concerned with carbohydrate metabolism, phosphorylation reactions and the citric acid cycle and with other metal in the activation of such enzymes as arginase, cystein, desulphydnase, deoxyribonuclease and yeast phosphatase. Apparently it is specific activator of the enzymes prolidase and glutomyl transferase. Antagonist relationship between $\mathrm{Fe}$ and $\mathrm{Mn}$ has been reported in soils and plants (Pathak et al., 1979) and likewise they influence yield of crop differently. Basen and Saxena (1970) ${ }^{[2]}$ and Jain (1973) obtained increased rice yield by the application of Fe and Mn. Ratios of Fe and Mn either in soil and plant have no significant impact on crop yield, only their addition in optimum concentration is of great significance (Agarwala and Associates, 1964) ${ }^{[1]}$. 
Such information available in this respect, so far is rather meagre in soils of Agra. Hence the study is being undertaken with a view to study the Fe and Mn interaction of yield, their content and uptake by Spinach crop.

\section{Materials and Methods}

A pot culture experiment was carried out using spinach crop in pot culture yard in the department of soil science and agriculture chemistry RBS College Bichpuri, Agra. The experimental soil was collected from research farm of RBS college the experimental soil was sandy loam in texture alkaline on reaction ( $\mathrm{pH} 8.0)$ with organic carbon content 3.4 $\mathrm{kg}$ per hectare, available $\mathrm{N} 160 \mathrm{~kg}$ per hectare, available phosphorus $8.4 \mathrm{~kg}$ per hectare, available potassium $115 \mathrm{~kg}$ per hectare, total Fe extracted with $\mathrm{HClO} 4$ (1.8\%), available FeDTPA (4.5 ppm), total Mn (350 ppm), determined by methods of Willard and Greathouse (1917) ${ }^{[12]}$, available Mn (7.0ppm) extracted with DPTA and determined colorimetrically by Willard and Greathouse (1917) ${ }^{[12]}$. The experiment comprising four levels $(0,5,10,20 \mathrm{ppm})$ of iron and four levels $(0,5,10,20 \mathrm{ppm})$ of manganese was conducted in a factorial randomised block design with three replications in 48 pots. Forty eight earthen pots of similar size and shape were selected clean and lined with polythene sheets after mixing the soil lot thoroughly $6 \mathrm{~kg}$ of soil was filled in each pot iron manganese were applied through ferrous sulphate and manganese sulphate respectively. The Basal doses of nitrogen Phosphorus and potassium were applied through urea single super phosphate and muriate of potash respectively at the time of sowing. The crop was raised with recommended agronomic practices. First cutting of spinach was done after 15 days of sowing followed by second cutting 20 days after first cutting. The yield data in regard to green foliage and dry matter were recorded at first and second cuttings. The samples were analysed for nitrogen content by modified Kjeldahl method (Jakson 1973). Phosphorus in diacid (HNO3: $\mathrm{HClO} 4)$ digest were determined by vanadomolybdate yellow colour method and flame photometre respectively. Iron and $\mathrm{Mn}$ in di-acid digest were determined on atomic absorption spectrophotometer uptake of nutrients was calculated by multiplying nutrient content with their respective dry matter yield.

\section{Results and Discussion \\ Yield}

The interaction effect of $\mathrm{Mn} \times \mathrm{Fe}$ on yields was found to be significant. An analysis of data given in table 1 reveals that the green foliage and dry matter yields at both cuttings and grains and straw yields of spinach at maturity were increased consistently with applied manganese under lower levels of iron. The yields of spinach were reduced under $20 \mathrm{ppm} \mathrm{Mn} \mathrm{in}$ the absence and presence of iron. The minimum yields of spinach at different stages of growth were recorded under 20 ppm $\mathrm{Mn}$ and $20 \mathrm{ppm} \mathrm{Fe}$ treatment. The maximum green foliage and dry matter yields at both cuttings and grains and straw yields at maturity were noted under $10 \mathrm{ppm}$ Fe and 10 ppm Mn treatment. Similar results were reported by Swarup and Mishra (1972) ${ }^{[10]}$.

Table 1: Green foliage, dry matter, straw yield and grain yield of spinach $\left(\mathrm{g} \mathrm{pot}^{-1}\right)$ as influenced by FexMn interaction at different stages of growth and maturity

\begin{tabular}{|c|c|c|c|c|c|c|c|c|}
\hline \multirow{2}{*}{ Fe levels (ppm) } & \multicolumn{4}{|c|}{ Mn levels (ppm) } & \multicolumn{4}{|c|}{ Mn levels (ppm) } \\
\hline & $\mathbf{0}$ & 5 & 10 & 20 & $\mathbf{0}$ & 5 & 10 & 20 \\
\hline \multicolumn{9}{|c|}{ First cutting } \\
\hline & \multicolumn{4}{|c|}{ Green foliage yield } & \multicolumn{4}{|c|}{ Dry matter yield } \\
\hline 0 & 16.0 & 16.5 & 16.9 & 15.5 & 1.3 & 1.5 & 1.6 & 1.8 \\
\hline 5 & 16.6 & 17.6 & 18.0 & 17.6 & 1.5 & 1.8 & 2.0 & 1.8 \\
\hline 10 & 17.4 & 19.5 & 20.0 & 17.6 & 1.8 & 2.3 & 2.4 & 1.8 \\
\hline 20 & 18.4 & 18.8 & 17.0 & 14.5 & 1.8 & 2.0 & 1.7 & 1.0 \\
\hline $\mathrm{CD} @(\mathrm{P}=0.05)$ & \multicolumn{4}{|c|}{0.49} & \multicolumn{4}{|c|}{0.148} \\
\hline \multicolumn{9}{|c|}{ Second cutting } \\
\hline & \multicolumn{4}{|c|}{ Green foliage yield } & \multicolumn{4}{|c|}{ Dry matter yield } \\
\hline 0 & 40 & 44 & 50 & 30 & 4.0 & 4.8 & 5.5 & 4.0 \\
\hline 5 & 44 & 46 & 47 & 35 & 4.7 & 5.1 & 5.5 & 3.9 \\
\hline 10 & 46 & 48 & 49 & 37 & 4.8 & 5.2 & 5.6 & 3.8 \\
\hline 20 & 44 & 44 & 44 & 35 & 4.5 & 4.6 & 4.5 & 3.5 \\
\hline $\mathrm{CD} @(\mathrm{P}=0.05)$ & \multicolumn{4}{|c|}{1.42} & \multicolumn{4}{|c|}{0.152} \\
\hline \multicolumn{9}{|c|}{ Maturity } \\
\hline & \multicolumn{4}{|c|}{ Straw yield } & \multicolumn{4}{|c|}{ Grain yield } \\
\hline 0 & 4.0 & 4.8 & 5.5 & 4.0 & 1.5 & 1.7 & 2.0 & 1.3 \\
\hline 5 & 4.7 & 5.1 & 5.6 & 3.9 & 1.8 & 2.1 & 2.0 & 1.5 \\
\hline 10 & 4.8 & 5.2 & 5.4 & 3.8 & 1.9 & 2.0 & 2.0 & 1.5 \\
\hline 20 & 4.5 & 4.6 & 4.5 & 3.5 & 1.8 & 1.8 & 1.6 & 1.3 \\
\hline$C D @(P=0.05)$ & \multicolumn{4}{|c|}{0.152} & \multicolumn{4}{|c|}{0.166} \\
\hline
\end{tabular}

\section{Chemical composition of plants at various cuttings}

It is clear from the data given in table-2 that $\mathrm{N}$ content in plants was increased significantly with every increase in the Mn level under all the $\mathrm{Fe}$ levels indicating synergistic relationship between $\mathrm{Mn}$ and $\mathrm{Fe}$ in respect of $\mathrm{N}$ content. The maximum $\mathrm{N}$ content in spinach plants at all stages of growth was recorded under $20 \mathrm{ppm} \mathrm{Mn}$ and $20 \mathrm{ppm}$ Fe treatment. The interaction effect of $\mathrm{Mn} \times \mathrm{Fe}$ on nitrogen content in spinach plants at various growth stages was found to be significant. While, the FexMn interaction did not have any significant effect on $\mathrm{P}$ content at all stages of growth of spinach plants. Singh and Singh (1975) [9] also reported similar findings. It is evident from the data presented in table2 that application of iron significantly increased the iron content in spinach plants at various cuttings under all the levels of manganese. But Mn addition tended to decrease the concentration of iron in the presence or absence of iron levels. The lowest level of iron was recorded under $20 \mathrm{ppm} \mathrm{Mn}+0$ ppm Fe treatment indicating an antagonistic effect of Mn on iron absorption by plants at various stages of growth. The data 
of table- 2 reveals that $\mathrm{Fe}$ addition reduced the $\mathrm{Mn}$ content significantly under all the levels of $\mathrm{Mn}$ indicating an antagonistic relationship between these two elements. The adverse effect of iron on $\mathrm{Mn}$ content was much more pronounced in the absence of $\mathrm{Mn}$ addition. The lowest concentration of $\mathrm{Mn}$ in spinach plants at various cuttings were noted under 0 ppm $\mathrm{Mn}+20 \mathrm{ppm}$ Fe treatment. Manganese addition on the other hand, increased its content significantly and maximum values were noted under $20 \mathrm{ppm} \mathrm{Mn+0} \mathrm{ppm}$ Fe treatment. The highest levels of Mn improved its content in the presence of $20 \mathrm{ppm} \mathrm{Fe}$ dose over control but lower level of Mn (5 PPM) failed to do so.

Table 2: Interaction effect of FexMn on chemical composition of spinach plants at various cuttings and maturity

\begin{tabular}{|c|c|c|c|c|c|c|c|c|}
\hline \multirow{4}{*}{ Fe levels (ppm) } & \multicolumn{4}{|c|}{ Mn levels (ppm) } & \multicolumn{4}{|c|}{ Mn levels (ppm) } \\
\hline & $\mathbf{0}$ & 5 & 10 & 20 & $\mathbf{0}$ & 5 & 10 & 20 \\
\hline & \multicolumn{8}{|c|}{ Nitrogen (\%) } \\
\hline & \multicolumn{4}{|c|}{ First cutting } & \multicolumn{4}{|c|}{ Second cutting } \\
\hline 0 & 2.30 & 2.35 & 2.92 & 2.50 & 1.90 & 1.90 & 1.96 & 2.04 \\
\hline 5 & 2.32 & 2.35 & 2.46 & 2.55 & 1.90 & 1.90 & 2.00 & 2.04 \\
\hline 10 & 2.38 & 2.39 & 2.48 & 2.55 & 1.96 & 1.98 & 2.02 & 2.06 \\
\hline 20 & 2.40 & 2.45 & 2.52 & 2.57 & 1.98 & 2.06 & 2.07 & 2.10 \\
\hline $\mathrm{CD} @(\mathrm{P}=0.05)$ & \multicolumn{4}{|c|}{0.02} & \multicolumn{4}{|c|}{0.025} \\
\hline \multicolumn{9}{|c|}{ Iron (ppm) } \\
\hline & \multicolumn{3}{|c|}{ First cutting } & \multicolumn{5}{|c|}{$\begin{array}{l}\text { Second cutting } \\
\end{array}$} \\
\hline 0 & 388 & 378 & 365 & 406 & 406 & 400 & 385 & 375 \\
\hline 5 & 418 & 410 & 396 & 380 & 436 & 427 & 410 & 400 \\
\hline 10 & 452 & 443 & 430 & 420 & 475 & 468 & 445 & 436 \\
\hline 20 & 468 & 457 & 445 & 438 & 500 & 488 & 465 & 452 \\
\hline $\mathrm{CD} @(\mathrm{P}=0.05)$ & \multicolumn{4}{|c|}{1.61} & \multicolumn{4}{|c|}{1.456} \\
\hline \multicolumn{9}{|c|}{ Manganese (ppm) } \\
\hline & \multicolumn{4}{|c|}{ First cutting } & \multicolumn{4}{|c|}{ Second cutting } \\
\hline 0 & 170 & 136 & 210 & 240 & 156 & 168 & 200 & 225 \\
\hline 5 & 156 & 168 & 196 & 220 & 140 & 156 & 180 & 200 \\
\hline 10 & 144 & 160 & 186 & 205 & 132 & 145 & 160 & 182 \\
\hline 20 & 128 & 140 & 160 & 185 & 116 & 128 & 140 & 175 \\
\hline $\mathrm{CD} @(\mathrm{P}=0.05)$ & \multicolumn{4}{|c|}{1.537} & \multicolumn{4}{|c|}{1.518} \\
\hline
\end{tabular}

\section{Chemical composition of nutrients at maturity}

It is evident from data given in table-3 that nitrogen content in straw and grain increase with every increase in Mn level under all the Fe level indicating synergistic relation between $\mathrm{Mn}$ and $\mathrm{Fe}$ in respect of $\mathrm{N}$ content. A further study of data presented in table-3 show that applications of iron significantly increased the iron content in straw and grain at maturity under all the levels of manganese. But Mn addition caused decrement in the content of iron in presence or absence of iron levels. The lowest value of iron concentration was noted with $20 \mathrm{ppm} \mathrm{Mn}+0$ ppm iron levels showing antagonistic effect of $\mathrm{Mn}$ on iron in straw and grain respectively. Similar tend is observed in Mn content of straw and grain that $\mathrm{Mn}$ concentration decrease as application of iron level increases. Minimum Mn concentration in grain and straw was recorded with $20 \mathrm{ppm} \mathrm{Fe}$ and $0 \mathrm{ppm}$ Mn levels. Similar results were reported by Gangwar (1986) ${ }^{[3]}$ (Lal et al. 2012 and Lal et al. 2016) ${ }^{[7,8]}$ that wheat crop responded to lower levels of iron and manganese applications. The application of iron reduced $\mathrm{Mn}$ content and vice versa.

Table 3: Nutrients content in straw and grain of spinach plants as affected by FexMn interaction at maturity of crop

\begin{tabular}{|c|c|c|c|c|c|c|c|c|}
\hline \multirow{3}{*}{ Fe levels (ppm) } & \multicolumn{4}{|c|}{ Mn levels (ppm) } & \multicolumn{4}{|c|}{ Mn levels (ppm) } \\
\hline & $\mathbf{0}$ & 5 & 10 & 20 & $\mathbf{0}$ & 5 & 10 & 20 \\
\hline & \multicolumn{8}{|c|}{ Nitrogen (\%) } \\
\hline & \multicolumn{4}{|c|}{ Straw } & \multicolumn{4}{|c|}{ Grain } \\
\hline 0 & 0.75 & 0.75 & 0.80 & 0.80 & 2.15 & 2.15 & 2.20 & 2.32 \\
\hline 5 & 0.76 & 0.78 & 0.80 & 0.82 & 2.15 & 2.14 & 2.20 & 2.27 \\
\hline 10 & 0.78 & 0.80 & 0.80 & 0.84 & 2.20 & 2.20 & 2.24 & 2.28 \\
\hline 20 & 0.80 & 0.80 & 0.85 & 0.88 & 2.23 & 2.27 & 2.30 & 2.35 \\
\hline $\mathrm{CD} @(\mathrm{P}=0.05)$ & \multicolumn{4}{|c|}{0.017} & \multicolumn{4}{|c|}{0.017} \\
\hline \multicolumn{9}{|c|}{ Iron (ppm) } \\
\hline & \multicolumn{4}{|c|}{ Straw } & \multicolumn{4}{|c|}{ Grain } \\
\hline 0 & 396 & 388 & 375 & 369 & 275 & 268 & 252 & 240 \\
\hline 5 & 425 & 418 & 404 & 390 & 296 & 290 & 275 & 265 \\
\hline 10 & 460 & 450 & 433 & 425 & 230 & 222 & 208 & 295 \\
\hline 20 & 475 & 467 & 450 & 440 & 260 & 250 & 240 & 230 \\
\hline $\mathrm{CD} @(\mathrm{P}=0.05)$ & \multicolumn{4}{|c|}{1.345} & \multicolumn{4}{|c|}{1.415} \\
\hline \multicolumn{9}{|c|}{ Manganese (ppm) } \\
\hline & \multicolumn{4}{|c|}{ Straw } & \multicolumn{4}{|c|}{ Grain } \\
\hline 0 & 90 & 110 & 136 & 168 & 132 & 148 & 172 & 195 \\
\hline 5 & 78 & 100 & 120 & 142 & 115 & 130 & 155 & 180 \\
\hline 10 & 65 & 80 & 100 & 125 & 92 & 112 & 138 & 157 \\
\hline 20 & 60 & 72 & 105 & 105 & 88 & 102 & 118 & 136 \\
\hline $\mathrm{CD} @(\mathrm{P}=0.05)$ & \multicolumn{4}{|c|}{1.463} & \multicolumn{4}{|c|}{0.148} \\
\hline
\end{tabular}




\section{Nutrients uptake}

The interaction effect of FexMn as reflected from the data given in table 4 that an uptake in grain and straw of spinach plants increased consistently with 5 and $10 \mathrm{ppm} \mathrm{Fe}$ application in presence or absence of applied $\mathrm{Mn}$. The highest level of Fe (20 ppm) failed to improve the $\mathrm{N}$ utilisation over $10 \mathrm{ppm}$ Fe level under all the levels of manganese. Similarly Mn application also enhanced the utilisation of nitrogen. The maximum values of $\mathrm{N}$ uptake in straw and grain of spinach were recorded under $10 \mathrm{ppm}$ Fe and $10 \mathrm{ppm} \mathrm{Mn}$ treatment. The higher levels of $\mathrm{Fe}$ and $\mathrm{Mn}$ were found to have an antagonistic effect on the utilisation of nitrogen. The interaction effect of FexMn on Fe uptake as seen from table-4 that 5 and $10 \mathrm{ppm}$ Mn levels increased the uptake of Fe when applied with 5 and $10 \mathrm{ppm}$ Fe level in grain and straw of spinach crop. Mn application @ 20 ppm showed an adverse effect on Fe uptake by spinach grain and straw. The minimum

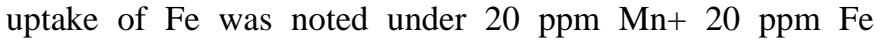
treatment. In respect of manganese it is evident from the data given in table 4 that application of $5 \mathrm{ppm}$ Fe increased the uptake of Mn by spinach grain under all levels of manganese. But all the levels of iron reduced the uptake of Mn by straw in presence or absence of manganese. The higher levels of iron (10 and $20 \mathrm{ppm}$ ) caused a significant reduction in manganese uptake indicating and antagonistic effect. The adverse effect of higher levels of iron on Mn uptake was much more pronounced in the presence of higher levels of manganese. The lowest value of $\mathrm{Mn}$ uptake by spinach grain was recorded under $20 \mathrm{ppm} \mathrm{Mn}$ and $20 \mathrm{ppm}$ Fe treatment. But in case of straw, the lowest value of Mn uptake was noted under $20 \mathrm{ppm}$ $\mathrm{Fe}+0$ ppm Mn treatment. (Lal et al. 2012 and Lal et al. 2016) $)^{[7,8]}$.

Table 4: Effect of Fe and Mn interaction on the uptake of nutrients $\left(\mathrm{mg} \mathrm{pot}^{-1}\right)$ by spinach crop at maturity

\begin{tabular}{|c|c|c|c|c|c|c|c|c|}
\hline \multirow{3}{*}{ Fe levels (ppm) } & \multicolumn{4}{|c|}{ Mn levels (ppm) } & \multicolumn{4}{|c|}{ Mn levels (ppm) } \\
\hline & $\mathbf{0}$ & 5 & 10 & 20 & $\mathbf{0}$ & 5 & 10 & 20 \\
\hline & \multicolumn{8}{|c|}{ Nitrogen } \\
\hline & \multicolumn{3}{|c|}{ Straw } & \multicolumn{5}{|c|}{ Grain } \\
\hline 0 & 30.0 & 36.0 & 40.0 & 32.0 & 27.9 & 32.2 & 34.0 & 27.8 \\
\hline 5 & 35.2 & 39.8 & 44.1 & 32.0 & 38.7 & 38.5 & 43.9 & 40.9 \\
\hline 10 & 37.5 & 41.6 & 43.3 & 31.9 & 39.6 & 50.5 & 53.8 & 41.1 \\
\hline 20 & 36.0 & 36.8 & 38.3 & 30.8 & 40.1 & 44.4 & 39.1 & 23.5 \\
\hline $\mathrm{CD} @(\mathrm{P}=0.05)$ & \multicolumn{4}{|c|}{1.743} & \multicolumn{4}{|c|}{3.170} \\
\hline & \multicolumn{8}{|c|}{ Iron } \\
\hline & \multicolumn{3}{|c|}{ Straw } & \multicolumn{5}{|c|}{ Grain } \\
\hline 0 & 0.16 & 0.18 & 0.21 & 0.17 & 0.36 & 0.41 & 0.41 & 0.30 \\
\hline 5 & 1.20 & 0.22 & 0.22 & 0.15 & 0.44 & 0.53 & 0.55 & 0.49 \\
\hline 10 & 0.23 & 0.24 & 0.23 & 0.16 & 0.42 & 0.52 & 0.51 & 0.50 \\
\hline 20 & 0.22 & 0.22 & 0.21 & 0.15 & 0.47 & 0.51 & 0.41 & 0.23 \\
\hline $\mathrm{CD} @(\mathrm{P}=0.05)$ & \multicolumn{4}{|c|}{0.015} & \multicolumn{4}{|c|}{0.037} \\
\hline \multicolumn{9}{|c|}{ Manganese } \\
\hline \multicolumn{4}{|c|}{ Straw } & \multicolumn{5}{|c|}{ Grain } \\
\hline 0 & 0.36 & 0.53 & 0.75 & 0.64 & 0.17 & 0.22 & 0.28 & 0.24 \\
\hline 5 & 0.37 & 0.51 & 0.66 & 0.56 & 0.18 & 0.23 & 0.32 & 0.33 \\
\hline 10 & 0.32 & 0.42 & 0.54 & 0.48 & 0.17 & 0.26 & 0.34 & 0.28 \\
\hline 20 & 0.27 & 0.34 & 0.41 & 0.37 & 0.16 & 0.21 & 0.21 & 0.14 \\
\hline $\mathrm{CD} @(\mathrm{P}=0.05)$ & \multicolumn{4}{|c|}{0.016} & \multicolumn{4}{|c|}{0.016} \\
\hline
\end{tabular}

\section{References}

1. Agarwala SC. associates Annual Progress Report of I.C.A.R. Scheme Micronutrients status of U.P. soils for the year 1963-1964.

2. Baser BL, Saxena SN. Manganese and iron absorption by different crop species grown in soils of Rajasthan. J Indian Soc. Soil Sci 1970;12:421-427.
3. Gangwar MS. studies on iron and manganese in soil of Rohilkhand region of Uttar Pradesh "Ph.D. thesis Agra university Agra 1986.

4. Jackson ML. Soil chemical analysis prentice Hall of India Pvt. Ltd. New Delhi 1967.

5. Kanwar JS, Randhawa NS. Micronutrient Research in soil and plants in India. A review I. C. A. R. New Delhi 1974.

6. Katyal JC. Research achievements of All India coordinated schem of micronutrients in soil and plants Fertil. News 1985;30:(4):67-80.

7. Lal Munna, Nataraja KC, Kherawat BS Brajendra, Kumar Arvind. Effect of nitrogen and manganese on yield and uptake of nutrients by oats (Avena sativa L.). An Asian Journal of Soil Science 2012;7(1):127-13.

8. Lal Munna, Anil Kumar Pal, Mahesh Chand Agrawal, Usha Rani K, Suma Chandrika D, Abhay Pratap Singh, et al. Effect of phosphorus and molybdenum on yield and nutrient uptake of faba bean in alluvial soil. Annals of Plant and Soil Research 2016;18(3):262-265

9. Singh S, Singh SB. Effect of application of iron and manganese on their uptake and yield of rice. J. Indian Soc. Soil Sci 1975;23:489-493.

10. Swarup A, Mishra B. Effect of ferrous sulphate on the availability of manganese. J Indian Soc. Soil Sci 1972;20:417-419.

11. Takkar PN, Randhawa NS. Micronutrients in Indian Agriculture Fertil. News 1978;23(8):3-26.

12. Willard HH, Greathoise LH. colorimetric determination of manganese of oxidation with perfiodate $\mathrm{J}$ Am. chem. Soc 1917;36:2366-2377. 